Relations industrielles

Industrial Relations

\title{
Relations du travail : Nouvelles orientations, Centre des dirigeants d'entreprise, Montréal, Quinze, 1978, 150 pp.
}

\section{Gérard Dion}

Volume 34, numéro 3, 1979

URI : https://id.erudit.org/iderudit/028995ar

DOI : https://doi.org/10.7202/028995ar

Aller au sommaire du numéro

Éditeur(s)

Département des relations industrielles de l'Université Laval

ISSN

0034-379X (imprimé)

1703-8138 (numérique)

Découvrir la revue

Citer ce compte rendu

Dion, G. (1979). Compte rendu de [Relations du travail : Nouvelles orientations, Centre des dirigeants d'entreprise, Montréal, Quinze, 1978, 150 pp.] Relations industrielles / Industrial Relations, 34(3), 614-615.

https://doi.org/10.7202/028995ar

Tous droits réservés @ C Département des relations industrielles de l'Université Laval, 1979
Ce document est protégé par la loi sur le droit d'auteur. L’utilisation des services d'Érudit (y compris la reproduction) est assujettie à sa politique d'utilisation que vous pouvez consulter en ligne.

https://apropos.erudit.org/fr/usagers/politique-dutilisation/ 


\section{RECENSIONS}

\section{BOOK REVIEWS}

Relations du travail: Nouvelles orientations,

Centre des dirigeants d'entreprise, Montréal, Quinze, 1978, 150 pp.

Les lecteurs de Relations industrielles ont déjà eu la possibilité de prendre connaissance en primeur de l'essentiel de la première partie de cet ouvrage (R.I. vol. 33, 1978, no 2) auquel des transformations mineures ont été ajoutées. Cependant on trouvera une section très considérable intitulée «de la théorie à la pratique» comprenant l'exposé de cinq expériences que des entreprises du Québec ont effectuées dans leur style de gestion pour la rendre plus participative.

Il nous apparaît que cet ouvrage marque une date importante dans l'évolution de la pensée patronale au Québec et dans le Canada.

L'analyse de la situation qui existe dans le monde du travail, le diagnostic posé, les valeurs mises de l'avant et les solutions préconisées dénotent la ferme volonté de s'attaquer à l'essentiel avec une attitude positive marquée à la fois de réalisme et d'idéalisme.

Même s'il est évident pour tous que le statu quo ne peut pas se prolonger sans préjudice grave pour l'économie et l'ensemble de la société, on ne s'attarde pas à larmoyer sur un passé idyllique et on ne se contente pas d'attitudes purement défensives. Bien au contraire, on se tourne courageusement vers l'avenir à la lumière d'une philosophie progressiste qui tient compte de toutes les valeurs humaines, économiques et sociales engagées dans les relations professionnelles.
Il faut avoir du courage pour dire que les employeurs ont les syndicats qu'ils méritent et pour affirmer: «On a trop longtemps considéré l'autorité comme un privilège indivisible qui confère à ses détenteurs un droit absolu sur l'orientation des ressources humaines et matérielles de l'entreprise». Le libéralisme économique est une doctrine carrément désuète et même si l'on maintient le droit de propriété et la libre entreprise, l'un et l'autre sont grevés d'obligations sociales qui doivent amener des transformations dans les attitudes et les structures. Et l'on doit s'orienter vers des formes de participation. Et les employeurs doivent en prendre l'initiative.

Comme il va de soi, puisqu'il s'agit d'un groupement de dirigeants d'entreprise, le document aborde les problèmes des relations du travail en insistant sur les transformations que les dirigeants doivent apporter au niveau même de l'entreprise. Elles ont l'avantage d'être à la portée de leur action directe et de leur zone d'influence. Il ne faudrait cependant pas oublier que si l'entreprise est le lieu privilégié des rapports du travail et le seul immédiatement accessible, l'action à ce niveau ne suffira pas à réaliser tous les objectifs poursuivis. En effet, les divers agents dans l'entreprise sont grandement influencés par toutes les frustrations qu'ils éprouvent dans la société globale et il n'y a pas nécessairement une adéquation entre la satisfaction au travail et la productivité.

Ce qui donne du poids à pareille prise de position, c'est d'abord qu'elle n'est pas seulement une rêverie de réformateurs de salon, 
mais qu'elle est le fruit d'une réflexion élaborée par des personnes possédant des responsabilités dans des entreprises dont les résultats ont ensuite été acceptés au cours d'une assemblée générale du CDE. C'est encore qu'elle n'est pas seulement, comme on le trouve trop souvent, une revendication auprès des syndicats et du gouvernement, mais un appel aux employeurs eux-mêmes de changer leurs attitudes et de faire les premiers pas.

Ce manifeste du Centre des dirigeants d'entreprise constitue un véritable défi à la conscience des employeurs, des travailleurs, des dirigeants syndicaux et des gouvernants. Et ce n'est pas sans raison que le ministre du Travail du Québec l'a qualifié de «bouffée d'air frais» dans le climat des relations de travail.

Gérard DION

Université Laval

Industrial Democracy in Western Europe, $A$ North American Perspective, by John Crispo, Toronto, McGraw-Hill Ryerson, 1978, $181 \mathrm{pp}$.

In order to avoid changes coming to our industrial relations system just by default, and not by the well calculated and prepared design, it is necessary not only to know very well the existing weaknesses but in addition to have a good forsight of new developments, as well as to learn about the foreign experience. J. Crispo analyses the Western European experience of industrial democracy in relation to the urgent needs of our system as seen by him: strenghtening of checks and balances which preclude any one interest group for acquiring and utilizing too much power, the supplementation of the conflict-oriented collective bargaining by some more co-operative forms of union-management interaction, the avoidance of a too much governmental interference, overcoming of the great fragmentation and decentralization of collective bargaining in at least some industries, the much better information of labour by employers on issues vital to bargaining, a widened scope of bargaining. According to J. Crispo, "The idea of a free collective bargaining system functioning almost oblivious to national economic and social developments and priorities is becoming increasingly untenable $/ . . . /$ The ultimate choice now beginning to confront all modern industrialized societies is between highly bureaucratized and centralized corporate and technocratic systems and series of reasonably well balanced and interdependent quasiautonomous sub-systems. Collective bargaining could prove to be one of the first of these sub-systems of democratic pluralism to be jeopardized if the choice even begins to go the wrong way. For this reason labour and management could be risking everything if they do not consider more carefully, earnestly and openly all of the alternatives which are still freely available to them"' (pp. 152, 153, 174).

In Western Europe there is a trend towards the codecision-making arrangement at various levels of industrial relations, including the shop-floor democracy. Collective bargaining between unions and management is widely supplemented by various forms of employee representation on company boards, works councils, etc. There is usually much more political involvement and commitment than in North America. The negotiations promoted at the national or regional level are supplemented by the local additional agreements in which several parties, not only unions and management, may be involved. "Lacking elaborate formal contracts within which to operate, Western European managers and workers are much more disposed to enter into informal understandings. The need is obviously present, and there is less reason to fear the results as they are unlikely to prove binding on either side in their later relations"' (p. 38).

The systems of industrial relations in Western Europe vary from a consensual model to the class conflict model. However, there is a general tendency towards the multiplication of forms within which 